\title{
Pawpaw [Asimina triloba (L.) Dunal] Fruit Ripening. II. Activity of Selected Cell-wall Degrading Enzymes
}

\author{
Rumphan Koslanund ${ }^{1}$ \\ Post-Harvest Products and Processing Research and Development Office, Department of Agriculture, \\ Bangkok, Thailand \\ Douglas D. Archbold ${ }^{2}$ \\ Department of Horticulture, University of Kentucky, Lexington, KY 40546-0091 \\ Kirk W. Pomper ${ }^{3}$ \\ USDA National Clonal Germplasm Repository for Asimina spp., Atwood Research Facility, Kentucky \\ State University, Frankfort, KY 40601-2355
}

\begin{abstract}
AdDitional INDEX WORDS. fruit firmness, pectin methylesterase, polygalacturonase, endo- $(1 \rightarrow 4) \beta$-D-glucanase, endo- $\beta$ - $1,4-$ mannanase

Abstract. Pawpaw fruit were harvested at the advent of the ripening process and were ripened at room temperature. Based on fruit firmness and respiration and ethylene production rates at harvest and during ripening, fruit were classified into one of four categories: preripening (no to very slight loss of firmness; preclimacteric), early ripening (some softening; increasing rates of ethylene and $\mathrm{CO}_{2}$ production), mid-ripening (soft; at or just past climacteric), and late ripening (very soft; postclimacteric). The activities of the cell-wall degrading enzymes polygalacturonase (PG), endo$(1 \rightarrow 4)$ B-D-glucanase (EGase), and endo-(3-1,4-mannanase (MAN) were low in the preripening and early ripening stages, increased dramatically by mid-ripening coincident with the respiratory and ethylene climacterics, and decreased at late ripening. However, pectin methylesterase (PME) activity per milligram protein was highest at the green stage when the fruit firmness was high and decreased as ripening progressed. Tissue prints indicated both EGase and MAN increased as ripening proceeded. The EGase activity was evident near the seeds and the surface of the fruit at preripening and eventually spread throughout, while MAN activity was evident near the fruit surface at preripening and was progressively expressed throughout the flesh as fruit ripened. The greatest decline in fruit firmness occurred between pre- and early ripening, before the peak activities of PG, EGase, and MAN, although MAN exhibited the greatest relative increase of the three enzymes in this period. The data suggest that PME may act first to demethylate polygalacturonate and may be followed by the action of the other enzymes resulting in cell wall disassembly and fruit softening in pawpaw.
\end{abstract}

Pawpaw fruit soften rapidly after harvest (Archbold and Pomper, 2003; McGrath and Karahadian, 1994), and this hinders the development of efficient and rapid handling and marketing strategies for the fruit. Softening is an important part of the ripening process, and it is well documented that changes in cell walls accompany fruit softening (Brummell and Harpster, 2001; Seymour and Gross, 1996). Plant cell walls are highly complex structures consisting of many types of complex polysaccharides and numerous proteins (Carpita and Gibeaut, 1993). Pectins, hemicelluloses, and cellulose comprise the major groups of polysaccharides in plant cell walls (Seymour and Gross, 1996), with more than $50 \%$ as pectin (Brummell and Harpster, 2001). Cell wall metabolism is tightly controlled through regulation of both gene expression and the cell wall microenviroment (Seymour and Gross, 1996). Due to the structural complexity of the primary cell wall, a coordinated effort of a variety of enzymes affecting both covalent and noncovalent bonds is likely involved in cell wall disassembly and fruit softening (Giovannoni et al., 1992).

Other species within the Annonaceae family that includes pawpaw also soften rapidly once ripening begins (Brown et al.,

Received for publication 26 May 2004. Accepted for publication 14 Jan. 2005. ${ }^{1}$ Former: Graduate Student, Dept. of Horticulture, Univ. of Kentucky, Lexington, KY 40546-0091.

2Professor of Horticulture. To whom reprint requests should be addressed.

${ }^{3}$ Principal Investigator of Horticulture and Curator.
1988). Cherimoya (Annona cherimola Mill.), perhaps the most popular member of the family (Merodio and De La Plaza, 1997), exhibits a rise in polygalacturonase (PG) protein (Del Cura et al., 1996) and activity (Sanchez et al., 1998) as softening progresses, and the increase in PG-protein was delayed under high $\mathrm{CO}_{2}$ storage that also retarded fruit softening. This suggests that polygalacturonase may be involved in cell wall softening, though its exact role and significance may vary among species (Hadfield and Bennett, 1998). In addition, endo- $(1 \rightarrow 4) \beta$-D-glucanase (EGase) also has been reported to increase in cherimoya in the same period (Sanchez et al; 1998), and it too has been implicated in fruit softening (Maclachlan and Brady, 1994). De-esterification of polygalacturonic chains by pectin methylesterase (PME) may make the chains more susceptible to PG degradation (Carpita and Gibeaut, 1993), facilitating rapid loss of cell wall structure. The presence and activity of PME in other fruit of the Annonaceae family has not been studied. Endo- $\beta$-mannanase (MAN) has more recently been implicated in fruit cell wall degradation (Bewley et al., 2000), though it has not been reported for any of the Annonaceae.

In order to maintain fruit firmness and extend pawpaw shelf life and storage, and to identify targets for molecular manipulation, a greater understanding of the biochemical basis of fruit softening in this species is required. The goal of this study was to determine the existence and activities of four important fruit cell-wall degrading enzymes, PG, PME, EGase, and MAN, and their relationship to loss of firmness during pawpaw fruit ripening. 


\section{Materials and Methods}

Plant material. Pawpaw fruit were harvested from over 20 genotypes at the Kentucky State Univ. Research Farm, Frankfort, on several dates in 2000 and 2001. Because the intent was to characterize general trends of pawpaw ripening, not possible clonal differences, the fruit from the different genotypes were pooled for use. Immediately following harvest, fruit were transported to the laboratory at the Univ. of Kentucky.

Starting on each harvest date, fruit were weighed and then ripened at ambient temperature $\left(22 \pm 2^{\circ} \mathrm{C}\right)$ on the lab bench. Due to the lack of uniformity in maturity stage at harvest, ripening stages were defined from daily ethylene and $\mathrm{CO}_{2}$ production rates and external firmness (techniques in Koslanund et al., 2005) as follows: preripening (no to very slight loss of firmness; low respiration and ethylene production), early ripening (some softening; increasing rates of ethylene and $\mathrm{CO}_{2}$ production), mid-ripening (soft; at or just past the climacteric with the highest rates of respiration and ethylene production), and late ripening (very soft; postclimacteric with low respiration and ethylene production). Fruit were at either the preripening, early ripening, and mid-ripening stages at harvest, and on each day of postharvest ripening at least two of the above classes of fruit could be identified. During ripening, subsamples of fruit were peeled, sectioned, and placed in $-80^{\circ} \mathrm{C}$ storage for subsequent enzyme analyses.

Polygalacturonase extraction AND assay. A modification of the method of Sanchez et al. (1998) was used for the extraction of PG. Ten grams of frozen flesh tissue were ground to a powder in liquid $\mathrm{N}_{2}$ by using a mortar and pestle and homogenized (Omni 5000; Omni Intl., Gainesville, Va.) in $30 \mathrm{~mL}$ of $50 \mathrm{~mm}$ sodium acetate buffer ( $\mathrm{pH} 7.0$ ) containing $5 \mathrm{~mm}$ dithiothreitol(DTT), $0.1 \mathrm{M}$ $\mathrm{NaCl}, 5 \%$ glycerol (v/v), and $1 \%(\mathrm{w} / \mathrm{v})$ polyvinylpolypyrrolidone (PVPP). The homogenate was centrifuged at $9800 g_{\mathrm{n}}$ and $4{ }^{\circ} \mathrm{C}$ for $20 \mathrm{~min}$. The pellet obtained after centrifugation was suspended in $10 \mathrm{~mL}$ sodium acetate buffer ( $\mathrm{pH}$ 6.5) containing $5 \mathrm{~mm}$ DTT, $1 \mathrm{M} \mathrm{NaCl}, 5 \%$ glycerol (v/v), and 1\% PVPP (w/v) and stirred 15 $\mathrm{min}$. The homogenate was then centrifuged at $24,000 \mathrm{~g}_{\mathrm{n}}$ and $4{ }^{\circ} \mathrm{C}$ for $20 \mathrm{~min}$. A $10 \mathrm{~mL}$ aliquot of the supernatant was made to $80 \%$ ammonium sulfate to precipitate protein. During precipitation, the solution was placed on ice for $30 \mathrm{~min}$ and was subsequently centrifuged at $30,000 g_{\mathrm{n}}$ for $20 \mathrm{~min}$. The pellet was suspended in 2 $\mathrm{mL} 50 \mathrm{~mm}$ sodium acetate buffer ( $\mathrm{pH} 6.5)$ and dialyzed overnight with cellulose membrane (12,000 molecular weight cutoff; Sigma Chemical Co., St. Louis) in a 2-L flask against $50 \mathrm{~mm}$ sodium acetate buffer ( $\mathrm{pH}$ 6.5) with 2 changes of buffer. The dialyzed extract was centrifuged, and the supernatant was used for the enzyme assays. All procedures were carried out at $4{ }^{\circ} \mathrm{C}$.

Polygalacturonase activity was determined by the method of Gross (1982). Reaction mixtures consisted of $150 \mu \mathrm{L}$ of 100 mM sodium acetate buffer ( $\mathrm{pH} 5.0$ ) containing $0.1 \mathrm{M} \mathrm{NaCl}, 1 \%$ polygalacturonic acid (washed with $80 \%$ ethanol 6 times prior to use), and $50 \mu \mathrm{L}$ of extracted enzyme. The mixtures were incubated at $30^{\circ} \mathrm{C}$ for $3 \mathrm{~h}$ with continuous shaking. The reactions were terminated with $1 \mathrm{~mL}$ of cold $100 \mathrm{~mm}$ borate buffer $(\mathrm{pH}$ 9). Then $0.2 \mathrm{~mL}$ of $1 \% 2$-cyanoacetamide were added, and the samples were mixed and immersed in a boiling water bath for 10 min. After cooling to room temperature, the absorbance at 276 $\mathrm{nm}$ was determined using a Cary 50 spectrophotometer (Varian, Walnut Creek, Calif.). Reaction solutions without substrate were used as controls, and extracts boiled 30 min were used as negative controls to assure the validity of the activity measurements. A calibration curve was obtained using D-galacturonic acid as standard. PG activity was expressed as galacturonic acid reducing equivalents produced per unit protein per $\mathrm{h}\left(\mu \mathrm{mol} \cdot \mathrm{mg}^{-1} \cdot \mathrm{h}^{-1}\right)$.

ENDO-(1 $\rightarrow 4) B$-D-GLUCANASE EXTRACTION AND ASSAY. Endo$(1 \rightarrow 4) \beta$-D-glucanase was extracted along with PG above. Reaction mixtures consisted of $350 \mu \mathrm{L}$ of $100 \mathrm{~mm}$ sodium acetate buffer (pH 5.5) containing $1 \%(\mathrm{w} / \mathrm{v})$ low-viscosity carboxymethyl cellulose, $0.1 \mathrm{M} \mathrm{NaCl}$, and $200 \mu \mathrm{L}$ of enzyme extract. The reaction was carried out for $6 \mathrm{~h}$ at $35^{\circ} \mathrm{C}$ with continuous shaking. After incubation, $1 \mathrm{~mL}$ PGO enzyme color reagent (Sigma) was added, and the solution was incubated at $37^{\circ} \mathrm{C}$ for $30 \mathrm{~min}$. The absorbance was read at $450 \mathrm{~nm}$. Reaction solutions without substrate were used as controls, and extracts boiled $30 \mathrm{~min}$ were used as negative controls to assure the validity of the activity measurements. A calibration curve was obtained using glucose as a standard. EGase activity was expressed as glucose produced per unit protein per hour $\left(\mu \mathrm{mol} \cdot \mathrm{mg}^{-1} \cdot \mathrm{h}^{-1}\right)$.

Pectin Methylesterase eXtraction and assay. Ten grams of frozen flesh tissue were ground in liquid $\mathrm{N}_{2}$ using a mortar and pestle and homogenized in $30 \mathrm{~mL}$ of $8.8 \% \mathrm{NaCl}(\mathrm{pH} 7.55)$. The homogenate was centrifuged at $20,000 g_{\mathrm{n}}$ and $4{ }^{\circ} \mathrm{C}$ for $10 \mathrm{~min}$, and the supernatant was filtered through 1 layer of Miracloth (Calbiochem, EMD Biosciences, La Jolla, Calif.). Reaction mixtures consisted of $2 \mathrm{~mL}$ substrate solution (1\% citrus pectin, $0.1 \mathrm{~m}$ phosphate buffer ( $\mathrm{pH} 7.5$ ), $5 \mathrm{~mm}$ p-nitrophenyl acetate, and $100 \mu \mathrm{L}$ of crude extract. The reaction was carried out for 1 $\mathrm{h}$ at $30^{\circ} \mathrm{C}$. After the incubation, $7 \mathrm{~mL}$ of $0.1 \mathrm{~m}$ phosphate buffer (pH 7.0) was added and samples were read at $400 \mathrm{~nm}$. Reaction solutions without substrate were used as controls, and extracts boiled $30 \mathrm{~min}$ were used as negative controls to assure the validity of the activity measurements. A calibration curve was used with $p$-nitrophenol as a standard. PME activity was expressed as $p$-nitrophenol produced per unit protein $\left(\mu \mathrm{mol} \cdot \mathrm{mg}^{-1} \cdot \mathrm{h}^{-1}\right)$.

ENDO-ß-MANNANASE EXTRACTION AND ASSAY. Endo- $\beta$-mannanase was extracted and assayed by the method of Nonogaki et al. (1992) with some modification. Ten grams of frozen flesh tissue were ground to a powder in liquid $\mathrm{N}_{2}$ using a mortar and pestle and homogenized in $30 \mathrm{~mL}$ of $0.1 \mathrm{M}$ citric acid and $0.2 \mathrm{M}$ sodium phosphate $(\mathrm{pH}$ 5.0). The homogenate was centrifuged at $10,900 g_{\mathrm{n}}$ and $4{ }^{\circ} \mathrm{C}$ for $10 \mathrm{~min}$. The supernatant was filtered through 1 layer of Miracloth. Reaction mixtures consisted of 600 $\mu \mathrm{L}$ of substrate solution, which contained $300 \mu \mathrm{L} 0.1 \mathrm{~m}$ citric acid in $0.2 \mathrm{M}$ sodium phosphate (pH 5.0), and $300 \mu \mathrm{L} 1 \%$ (w/v) locust bean gum solution dyed with Remazol Brilliant Blue R (Sigma) (McCleary, 1978), and $600 \mu \mathrm{L}$ of crude extract. The reaction was carried out for $1.5 \mathrm{~h}$ at $30^{\circ} \mathrm{C}$ and was terminated by adding $1.4 \mathrm{~mL} 80 \%$ ethanol. After centrifugation, the absorbance of the supernatant was determined spectrophotometrically at $590 \mathrm{~nm}$. Reaction solutions without substrate were used as controls, and extracts boiled $30 \mathrm{~min}$ were used as negative controls to assure the validity of the activity measurements. Enzymatic cleavage of mannan polymers released the bound dye into the solution. Activity was determined in relation to the activities of a serial dilution of commercial MAN (Megazyme; North Rocks, Sydney, Australia) with hydrolyzed dyed locust bean gum as standard. MAN activity was expressed as mannose produced per unit protein per hour $\left(\mu \mathrm{mol} \cdot \mathrm{mg}^{-1} \cdot \mathrm{h}^{-1}\right)$.

Protein measurement. Protein content of each enzyme extract used for assay was determined by the method of Bradford (1976) using a Bio-Rad protein assay kit and bovine serum albumin (BSA) as standard.

TisSUe PRINT TECHNIQUE. A tissue print technique for MAN and EGase distribution within the fruit flesh was performed by the 
methods of Downie et al. (1994). Fruit were cut in half, and the cut surface was placed for $1 \mathrm{~h}$ on a $5-\mathrm{mm}$-thick $5 \%$ acrylamide gel backed on gel bond film containing $0.1 \%(\mathrm{w} / \mathrm{v})$ locust bean gum for MAN or $0.1 \%(\mathrm{w} / \mathrm{v})$ carboxymethyl cellulose for EGase. The gels were then placed on wet paper towels in a closed container to prevent them from drying. After fruit removal, the gels were further incubated $16 \mathrm{~h}$ at room temperature and stained with $0.5 \%$ or $0.1 \%$ Congo red for MAN and EGase, respectively. Circular images of each fruit were captured around the periphery of each fruit with a digital scanner for the illustrations. Light gray to white areas indicate low to high enzyme activity, respectively.

Data AnAlysis. To determine if ripening class means for enzyme activities varied significantly, data were analyzed using SAS (SAS Institute, Cary, N.C.), and means were separated by least significant difference at $P=0.05$.

\section{Results and Discussion}

Fruit were grouped by firmness and ethylene and $\mathrm{CO}_{2}$ production rates. Four stages of ripening were defined, as described earlier: preripening (no softening; preclimacteric), early ripening (some softening; increasing rates of ethylene and $\mathrm{CO}_{2}$ production), mid-ripening (soft; at or just past climacteric), and late ripening (very soft; postclimacteric). From an analysis of all the fruit across both harvest years, each stage exhibited a distinct combination of mean values for fruit firmness, ethylene production, and respiration rate (Table 1). The greatest decline in fruit firmness occurred from the pre- to the early ripening stage, while the ethylene and respiratory climacterics occurred afterwards in the mid-ripening stage as has been previously reported (Archbold and Pomper, 2003; Koslanund et al., 2005).

Polygalacturonase activity. In 2000, PG activity as galacturonic acid reducing equivalents produced per unit protein per $\mathrm{h}$ of $0.003 \mu \mathrm{mol} \cdot \mathrm{mg}^{-1} \cdot \mathrm{h}^{-1}$ was first detected at the preripening stage, and it increased slightly at early ripening to $0.06 \mu \mathrm{mol} \cdot \mathrm{mg}^{-1} \cdot \mathrm{h}^{-1}$ (Fig.1). PG activity then rose dramatically to $2.18 \mu \mathrm{mol} \cdot \mathrm{mg}^{-1} \cdot \mathrm{h}^{-1}$ at mid-ripening, a 37-fold increase, and subsequently decreased at late ripening. In 2001, PG activity was first detected at the early ripening stage with $0.24 \mu \mathrm{mol} \cdot \mathrm{mg}^{-1} \cdot \mathrm{h}^{-1}$, it increased to 3.33 $\mu \mathrm{mol} \cdot \mathrm{mg}^{-1} \cdot \mathrm{h}^{-1}$ at the mid-ripening stage, a 14 -fold increase, then decreased at late ripening.

The PG enzyme extract from pawpaw may contain a mixture of endo- and exo-PG, similar to that reported for cherimoya (Sanchez et al., 1998), but endo-PG is the major form for most species (Knee et al., 1991). A similar level and pattern of PG activity was observed in cherimoya (Del Cura et al., 1996; Sanchez et al., 1998), where PG activity increased 3-fold from harvest until day 3 . This coincided with the respiratory climacteric, the

Table 1. External firmness, ethylene production, and respiration rate of pawpaw fruit at four defined stages of ripening after harvest in 2000 and $2001 .^{2}$

\begin{tabular}{lccc}
\hline & $\begin{array}{c}\text { Firmness } \\
(\mathrm{N})\end{array}$ & $\begin{array}{c}\text { Ethylene } \\
\text { production } \\
\left(\mu \mathrm{g} \cdot \mathrm{kg}^{-1} \cdot \mathrm{h}^{-1}\right)\end{array}$ & $\begin{array}{c}\text { Respiration } \\
\text { rate } \\
{\left[\mathrm{CO}_{2}\left(\mathrm{mg} \cdot \mathrm{kg}^{-1} \cdot \mathrm{h}^{-1}\right)\right]}\end{array}$ \\
\hline Prage & $52 \pm 1$ & $5 \pm 1$ & $98 \pm 10$ \\
Early ripening & $27 \pm 1$ & $5 \pm 1$ & $134 \pm 6$ \\
Mid-ripening & $12 \pm 1$ & $10 \pm 1$ & $166 \pm 4$ \\
Late ripening & $4 \pm 1$ & $4 \pm 1$ & $164 \pm 11$ \\
\hline
\end{tabular}

zValues are the mean \pm SE on a per unit fresh weight basis for the preripening, early ripening, mid-ripening, and late ripening stages from 11 , 50, 160, and 52 measurements, respectively.

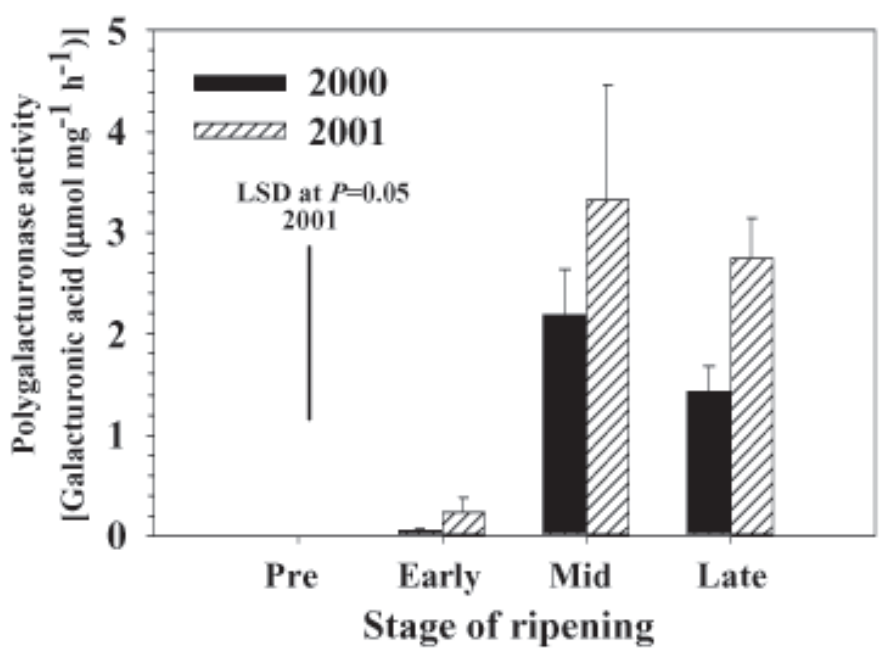

Fig. 1. Polygalacturonase activity at different stages of pawpaw ripening: Pre for preripening (no softening; preclimacteric); Early for early ripening (some softening; increasing rates of ethylene and $\mathrm{CO}_{2}$ production); Mid for midripening (soft; at or just past climacteric); and Late for late ripening (very soft; postclimacteric). Activity as galacturonic acid reducing equivalents produced per unit protein, or $\mu \mathrm{mol} \cdot \mathrm{mg}^{-1} \cdot \mathrm{h}^{-1}$. Each data point is the mean of six and four fruit in 2000 and 2001, respectively. Vertical bars on symbols represent SE of the mean. The separate vertical bars are Fisher's least significant difference (LSD) at $P=0.05$

beginning of the most pronounced rise in ethylene production, and the highest drop in flesh firmness. PG activity then declined. Del Cura et al. (1996) also reported that several PG-related proteins occurred from the unripe to ripe stages of cherimoya.

In most fruit $\mathrm{PG}$ is mainly responsible for the degradation of pectin during ripening (Brady, 1987; Fischer and Bennett, 1991; Giovannoni et al., 1989). In both slow- and fast-ripening fruit models, PG appears to play important roles in pectin disassembly, but it is probably not the sole enzyme responsible for the softening process (Giovannoni et al., 1989; Huber, 1984; McCollum et al., 1989).

ENDO-(1 $\rightarrow$ 4)B-D-GLUCANASE ACTIVITY. EGase activity as glucose produced per unit protein per $\mathrm{h}$ was first detected at the early ripening stage both years with values of $0.2 \mu \mathrm{mol} \cdot \mathrm{mg}^{-1} \cdot \mathrm{h}^{-1}$ in 2000 and $1.0 \mu \mathrm{mol} \cdot \mathrm{mg}^{-1} \cdot \mathrm{h}^{-1}$ in 2001 (Fig. 2). It increased dramatically to 1.1 and $2.6 \mu \mathrm{mol} \cdot \mathrm{mg}^{-1} \cdot \mathrm{h}^{-1}$ in 2000 and 2001 , respectively, at midripening, and then increased at late ripening in 2000 but slightly decreased in 2001. EGase activity (lighter areas) appeared first in the center of the fruit and activity spread outward as fruit ripening progressed (Fig. 3). In cherimoya (Sanchez et al., 1998) and sugar apple (Annona squamosa L.) (Tsay and Wu, 1989), EGase activity exhibited similar values and reached a maximum on day 3 after harvest, a 3-fold increase from initial levels. EGase activity is responsible for hemicellulose degradation and has been found in ripening fruit of most species (Brummell et al., 1994), but the amount varies considerably (Brummell and Harpster, 2001). The significance of the role of EGase in fruit softening appears to be species-specific (Brummell and Harpster, 2001).

Pectin methylesterase activity. PME activity as $p$-nitrophenol produced per unit protein per hour was present in preripening fruit at 4.4 and $3.3 \mu \mathrm{mol} \cdot \mathrm{mg}^{-1} \cdot \mathrm{h}^{-1}$ in 2000 and 2001 , respectively. It generally decreased as ripening progressed and was lowest at late ripening with 2.0 and $2.3 \mu \mathrm{mol} \cdot \mathrm{mg}^{-1} \cdot \mathrm{h}^{-1}$ in 2000 and 2001 , respectively (Fig. 4). However, in 2000 at mid-ripening PME activity was slightly greater than at early ripening. Atissue print also showed that PME activity was present in green mature fruit and throughout ripening, but no pattern was evident (data not shown). 




Fig. 2. Endo- $(1 \rightarrow 4) \beta$-D-glucanase activity at different stages of pawpaw ripening: Pre for preripening (no softening; preclimacteric); Early for early ripening (some softening; increasing rates of ethylene and $\mathrm{CO}_{2}$ production); Mid for mid-ripening (soft; at or just past climacteric); and Late for late ripening (very soft; postclimacteric). Activity as glucose produced per unit protein, or $\mu \mathrm{mol} \cdot \mathrm{mg}^{-1} \cdot \mathrm{h}^{-1}$. Each data point is the mean of 6 and 4 fruit in 2000 and 2001, respectively. Vertical bars on symbols represent SE of the mean. The separate vertical bars are Fisher's least significant difference (LSD) at $P=0.05$.

PME activity responsible for pectin de-esterification has also been found in the related sugar apple at harvest, and its activity gradually increased as ripening proceeded (Tsay and Wu, 1990). A diverse number of species have shown high PME activity at the beginning of ripening (Awad and Young, 1979; Gaffe et al., 1994; Iannetta et al., 1999; Paull and Chen, 1983; Trinchero et al., 1999; Tucker et al., 1982). The relatively high activity of PME in pawpaw during the earliest phase of ripening suggests that demethylation of polygalacturonic chains occurs as an antecedent to $\mathrm{PG}$ degradation of the chains.
ENDO-B-MANNANASE ACTIVITY. MAN activity as mannose produced per unit protein per $\mathrm{h}$ was 1.4 and $3.8 \mu \mathrm{mol} \cdot \mathrm{mg}^{-1} \cdot \mathrm{h}^{-1}$ at the preripening stage in 2000 and 2001, respectively, and it increased to 24.8 and $32.8 \mu \mathrm{mol} \cdot \mathrm{mg}^{-1} \cdot \mathrm{h}^{-1}$, respectively, in mid-ripening, 18- and 9- fold higher than the preripening stage (Fig. 5). The tissue prints also showed that MAN activities appeared when fruit began to soften slightly and were high by mid-ripening (Fig. 3 ). Initially, MAN activity (lighter areas) was mostly associated with the periphery of the fruit, but it moved inward as ripening progressed (Fig. 3). Other species have shown higher activities in the periphery of the fruit as well (Bourgault et al., 2001).

Increased MAN activity during ripening has been observed in some cultivars of tomato (Lycopersicon esculentum Mill.) (Bewley et al., 2000; Pressey, 1989; Sozzi et al., 1996). In the tomato cultivars Big Boy and Better Boy, the appearance of MAN activity in ripening fruit resembled the changes in $\mathrm{PG}$ activity, but MAN activity increased more markedly during the initial stages of ripening whereas PG activity increased gradually and was highest in overripe fruit (Pressey, 1989). In contrast, fruit of the tomato cultivars Walter and Heinz 1439 contained mRNA and protein for MAN and underwent normal development to the red-ripe stage; however they did not produce any MAN activity throughout fruit ripening (Banik et al., 2001). A cause and effect relationship between ripening and MAN activity has not been recognized, but most nonripening mutants of tomato such as rin and nor showed reduced softening and lower MAN activity (Bewley et al., 2000). MAN activity could be related to a process of reorganization in hemicellulose rather than disorganization (Bewley et al., 2000; Sozzi et al., 1996).

\section{Conclusion}

The activities of three putative fruit cell-wall degrading enzymes, PG, EGase, and MAN, were low in the preripening and
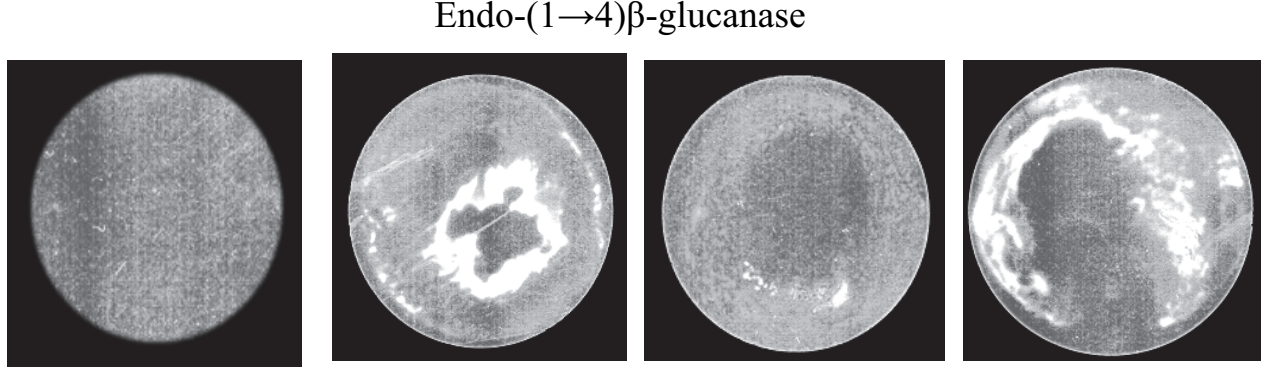

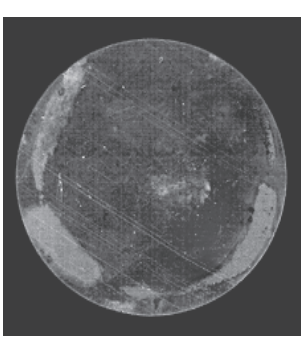

Pre

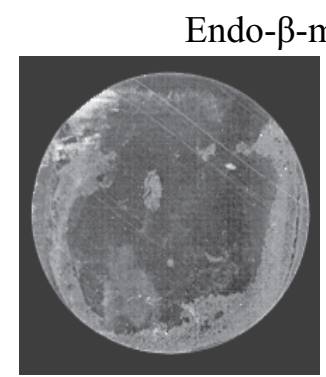

Early

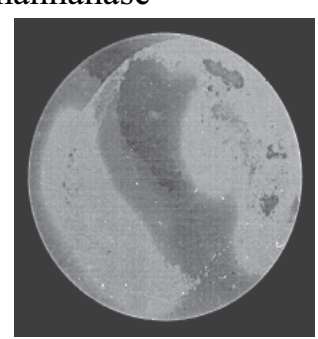

Mid

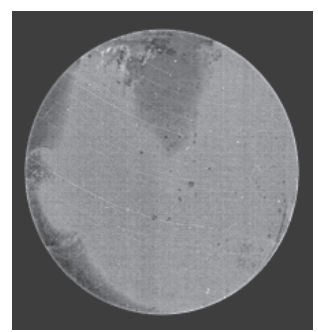

Late

\section{Stage of ripening}

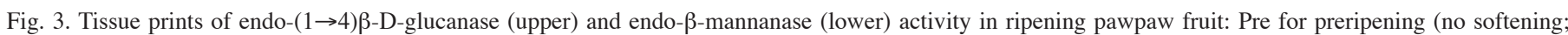


and Late for late ripening (very soft; postclimacteric). For both sets of prints, light gray to white areas indicate low to high enzyme activity, respectively. 




Fig. 4. Pectin methylesterase at different stages of pawpaw ripening: Pre for preripening (no softening; preclimacteric); Early for early ripening (some softening; increasing rates of ethylene and $\mathrm{CO}_{2}$ production); Mid for midripening (soft; at or just past climacteric); and Late for late ripening (very soft; postclimacteric). Activity as $p$-nitrophenol produced per unit protein, or $\mu \mathrm{mol} \mathrm{mg}^{-1} \mathrm{~h}^{-1}$. Each data point is the mean of 6 and 4 fruit in 2000 and 2001, respectively. Vertical bars on symbols represent SE of the mean. The separate vertical bars are Fisher's least significant difference (LSD) at $P=0.05$.

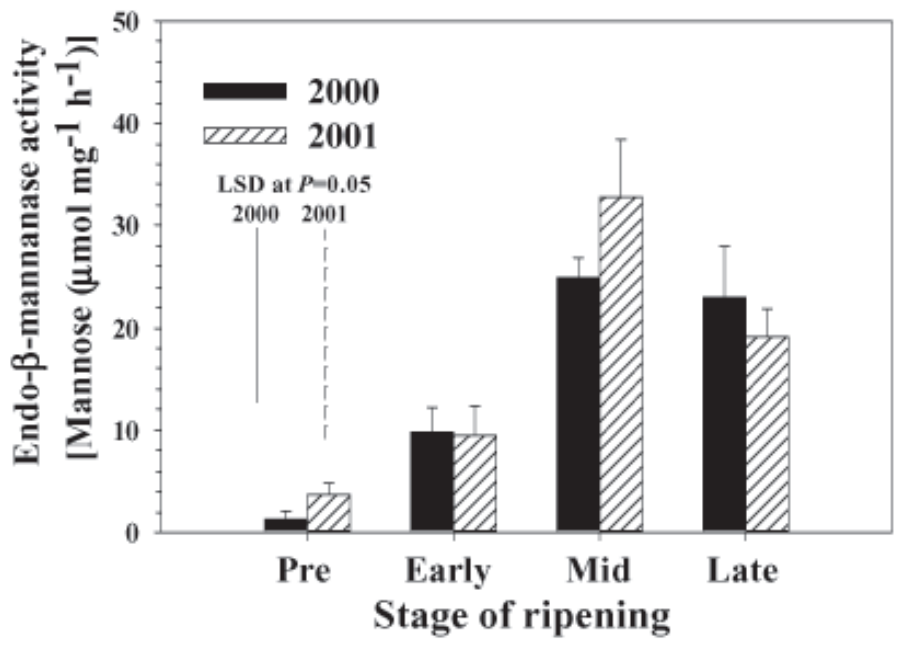

Fig. 5. Endo- $\beta$-mannanase activity at different stages of pawpaw ripening: Pre for preripening (no softening; preclimacteric); Early for early ripening (some softening; increasing rates of ethylene and $\mathrm{CO}_{2}$ production); Mid for midripening (soft; at or just past climacteric); and Late for late ripening (very soft; postclimacteric). Activity as mannose produced per unit protein, or $\mu \mathrm{mol} \mathrm{mg}^{-1}$ $\mathrm{h}^{-1}$. Each data point is the mean of 6 and 4 fruit in 2000 and 2001, respectively. Vertical bars on symbols represent SE of the mean. The separate vertical bars are Fisher's least significant difference (LSD) at $P=0.05$.

early ripening stages, increased dramatically at mid-ripening coincident with the respiratory and ethylene climacterics, and decreased slightly at late ripening. Tissue prints of EGase and MAN supported the activity assays. However, PME activity was highest at the green stage when the fruit firmness was high and decreased as ripening progressed. The loss of pawpaw fruit firmness was associated with low but increasing activities of PG, EGase, and MAN. Therefore, PME may first de-methylate polygalacturonic acid and make it more easily hydrolyzed by PG. The three other enzymes may each play a subsequent role in the softening of pawpaw during ripening. Thus, these four enzymes may work in concert to soften pawpaw fruit. Further study is needed to ascertain the possible involvement of other classes of enzymes, such as xyloglucan endotransglycosylase, $\alpha / \beta$-galactosidase, and expansins, that may also contribute to fruit softening in pawpaw.

\section{Literature Cited}

Archbold, D.D. and K.W. Pomper. 2003. Ripening pawpaw fruit exhibit respiratory and ethylene climacterics. Postharvest Biol. Tech. 30:99-103.

Awad, M. and R.E. Young. 1979. Postharvest variation in cellulase, polygalacturonase, and pectinmethylesterase in avocado (Persea americana Mill.cv. Fuerte) fruits in relation to respiration and ethylene production. Plant Physiol. 64:306-308.

Banik, M., R. Bourgault, and J.D. Bewley. 2001. Endo- $\beta$-mannanase is present in an inactive form in ripening tomato fruit of the cultivar Walter. J. Expt. Bot. 52:105-111.

Bewley, J.D., M. Banik, R. Bourgault, J.A. Feurtado, and P. Toorop. 2000. Endo-B-mannanase activity increases in the skin and outer pericarp of tomato fruits during ripening. J. Expt. Bot. 51:529-538.

Bourgault, R., J.D. Bewley, A. Alberici, and D. Decker. 2001. Endo- $\beta$ mannanase activity in tomato and other ripening fruits. HortScience 36:72-75.

Bradford, M.M. 1976. A rapid and sensitive method for quantitation of microgram quantities of protein utilizing the principal of protein-dye binding. Anal. Biochem. 72:248-254.

Brady, C.J. 1987. Fruit ripening. Annu. Rev. Plant Physiol. 38:155178.

Brown, B.I., L.S. Wong, A.P. George, and R.J. Nissen. 1988. Comparative studies on the postharvest physiology of fruit from different species of Annona (custard apple). J. Hort. Sci. 63:521-528.

Brummell, D.A., C.C. Lashbrook, and A.B. Bennett. 1994. Plant endo$1,4-\beta$-glucanases: Structure, properties and physiological function. Amer. Chem. Soc. Symp. Ser. 566:100-129.

Brummell, D.A. and M.H. Harpster. 2001. Cell wall metabolism in fruit softening and quality and its manipulation in transgenic plants. Plant Mol. Biol. 47:311-340.

Carpita, N.C. and D.M. Gibeaut. 1993. Structural models of the primary cell walls in flowering plants: Consistency of molecular structure with the physical properties of walls during growth. Plant J. 3:1-30.

Del Cura, B., M.I. Escribano, J.P. Zamorano, and C. Merodio. 1996. High carbon dioxide delays postharvest changes in RuBPCase and polygalacturonase-related protein in cherimoya peel. J. Amer. Soc. Hort. Sci. 121:735-739.

Downie, B., H.W.M. Hilhorst, and J.D. Bewley. 1994. A new assay for quantifying endo- $\beta$-mannanase activity using congo red dye. Phytochemistry 36:829-835.

Downie, B., L.M.A. Dirk, K.A. Hadfield, and T.A. Wilkins. 1998. A gel diffusion assay for quantification of pectin methylesterase activity. Anal. Biochem. 264:149-157.

Fischer, R.L. and A.B. Bennett. 1991. Role of cell wall hydrolases in fruit ripening. Annu. Rev. Plant Physiol. Plant Mol. Biol. 42:675-703.

Gaffe, J., D.M. Tieman, and A.K. Handa. 1994. Pectin methylesterase isoforms in tomato (Lycopersicon esculentum) tissues: Effects of expression of a pectin methylesterase antisense gene. Plant Physiol. 105:199-203.

Giovannoni, J.J., D. DellaPenna, A.B. Bennett, and R.L. Fischer. 1989. Expression of a chimeric polygalacturonase gene in transgenic rin (ripening inhibitor) tomato fruit results in polyuronide degradation but not softening. Plant Cell. 1:53-63.

Giovannoni, J.J., D. DellaPenna, A.B. Bennett, and R. Fischer. 1992. Polygalacturonase and tomato fruit ripening. Hort. Rev. 13:67-100.

Gross, K.C. 1982. A rapid and sensitive spectrophotometric method for assaying polygalacturonase using 2-cyanoacetamide. HortScience 17:933-934.

Hadfield, K.A. and A.B. Bennett. 1998. Polygalacturonases: Many genes in search of a function. Plant Physiol. 117:337-343.

Huber, D.J. 1984. Strawberry fruit softening: The potential roles of polyuronides and hemicelluloses. J. Food Sci. 49:310-1315.

Iannetta, P.P.M., J. Berg, R.E. Wheatley, R.J. McNicol, and H.V. Davies. 
1999. The role of ethylene and cell wall modifying enzymes in raspberry (Rubus idaeus) fruit ripening. Physiol. Plant. 105:338-347.

Knee, M., R.E. Paull, R. Ben-Arie, and J.S. Hawker. 1991. Enzymes in fruits, p. 545-598. In: P.F. Fox (ed.). Food enzymology. Elsevier Appl. Sci., London.

Koslanund, R., D.D. Archbold, and K.W. Pomper. 2005. Pawpaw [Asimina triloba (L.) Dunal] fruit ripening. I. Ethylene biosynthesis and production. J. Amer. Soc. Hort. Sci. 130:638-642.

Maclachlan, G. and C. Brady. 1994. Endo-1, 4- $\beta$-glucanase, xyloglucanase and xyloglucan endo-transglycosylase activities versus potential substrates in ripening tomatoes. Plant Physiol. 105:15-974.

McCleary, B.V. 1978. A simple assay procedure for $\beta$-D-mannanase. Carbohydrate Res. 67:213-221.

McCollum, T.G., D.J. Huber, and D.J. Cantliffe. 1989. Modification of polyuronides and hemicelluloses during muskmelon fruit softening. Physiol. Plant. 76:303-308.

McGrath,M.J. and C. Karahadian. 1994. Evaluation of physical, chemical, and sensory properties of pawpaw fruit (Asimina triloba) as indicators of ripeness. J. Agr. Food Chem. 42:968-974.

Merodio, C. and J.L. De La Plaza. 1997. Cherimoya, p. 269-288. In: S. Mitra (ed.). Postharvest physiology and storage of tropical and subtropical fruits. CABI, Wallingford, U.K.

Nonogaki, H., H. Matsushima, and Y. Morohashi. 1992. Galactomannan hydrolyzing activity develops during priming in the micropylar endosperm tip of tomato seeds. Physiol. Plant. 85:167-172.
Paull, R.E. and N.J. Chen. 1983. Postharvest variation in cell wall degrading enzymes of papaya (Carica papaya L.) during fruit ripening. Plant Physiol. 72: 382-385.

Pressey, R. 1989. Endo- $\beta$-mannanase in tomato fruit. Phytochemistry 28:3277-3280.

Sanchez, J.A., J.P. Zamorano, and R. Alique. 1998. Polygalacturonase, cellulase and invertase activities during cherimoya fruit ripening. J. Hort. Sci. Biol. 73:87-92.

Seymour, G.B. and K.C. Gross. 1996. Cell wall disassembly and fruit softening. Postharvest News Information 7:45N-52N.

Sozzi, G.O., O. Cascone, and A.A. Fraschina. 1996. Effect of a hightemperature stress on endo- $\beta$-mannanase and $\alpha$ - and $\beta$-galactosidase activities during tomato fruit ripening. Postharvest Biol. Technol. 9:49-63.

Trinchero, G.D., G.O. Sozzi, A.M. Cerri, F. Vilella, and A.A. Fraschina. 1999. Ripening-related changes in ethylene production, respiration rate and cell-wall enzyme activity in goldenberry (Physalis peruviana L.), a solanaceous species. Postharvest Biol. Technol. 16:139-145.

Tsay, L. and M.C. Wu. 1989. Studies on the postharvest physiology of sugar apple. Acta Hort. 258:287-294.

Tsay, L. and M.C. Wu. 1990. Studies on the physico-chemical properties of postharvest sugar apple. Acta Hort. 269:241-247.

Tucker, G.A., N.C. Robertson, and D. Grierson. 1982. Purification and changes in activities of tomato pectinesterase isoenzymes. J. Sci. Food. Agr. 33:396-400. 